\title{
Effect of Planting Dates on the Main Pests Attacking Squash Plants in Mansoura Region Awadalla, S. S. ${ }^{1}$; Hala A. K. El-Serafi ${ }^{1}$; M. E. El-Naggar ${ }^{2}$ and Marwa G. El-Mesawy ${ }^{2}$ \\ ${ }^{1}$ Economic Entomology Department, Fac. Agric., Mansoura Univ. \\ ${ }^{2}$ Field Crop Insect pest Department, Plant Protection Research Institute, Agricultural Research Center.
}

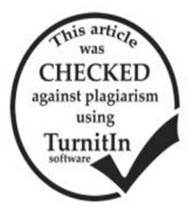

\begin{abstract}
The present experiments were conducted at the experimental farm belonging to the faculty of agriculture, Mansoura University. The squash plants (var. Eskandrani) was cultivated in the beginning of the third week of March, the first week of June, and the second week of August during the two successive seasons (2014 and 2015). The cotton aphid, Aphis gossypii recorded the highest relative abundance in March plantation during the first and second season of study (53.7 and $55.6 \%$, respectively) followed by Thrips tabaci (21.9 and $19.3 \%$, respectively). On the other hand, the potato leafhopper ranked the last category during the first and second season and represented by 2.3 and $2.1 \%$, respectively. While, the snake cucumber beetle Hensoepilachna argus did not occurred during the two seasons. In June plantation, A. gossypii recorded the highest relative abundance during the first and second season (39.4 and $26.6 \%$, respectively) followed by $H$. argus (20.9 and $24.3 \%$, respectively). While, in August plantation, $H$. argus ranked the first category during the first and second season and represented by 33.8 and $44.6 \%$, respectively. Moreover, during the two seasons, June plantation harbored the highest total numbers of the main pests and represented by 4590 and 3673 pests, respectively. The cotton mealybug, Phenacoccus solenopsis and the cotton whitefly Bemisia tabaci recorded the highest average number in August plantation during the two seasons with non-significant differences for $P$. solenospis and significant differences for $B$. tabaci. The snake cucumber beetle, $H$. argus recorded the highest average number for all stages in August plantation during the two seasons with non-significant differences during the first season and with significant differences during the second one.
\end{abstract}

\section{INTRODUCTION}

Cucurbit crops are considered one of the most important vegetable crops which used as a food in Egypt. Recently, a large sandy area was reclaimed and cultivated for years ago with different vegetable crops. Cucurbit crops under the present study are subjected to attack by a large range of insect pests such as aphids, thrips, whiteflies, and mealybugs which have a great economic importance and cause a serious damage (Abou El-Saad, 2015; Awadalla et al. 2011; Pourian et al. 2009; Refaei et al. 2016).

The host plant preference and sowing dates are essential components of integrated pest management (IPM) for different insect pests (El-fakharany, 2005; Younes et al., 2010; Zanic et al., 2013; Abdel-Hady et al. 2014; Refaei et al., 2016). Also, the snake cucumber beetle or the melon ladybird, Henosepilachna argus (Epilachna chrysomelina) (Geoffroy) is considered a serious insect pest of cucurbit crops in Egypt (Gameel and Abdel-Gaid, 2007; Awadalla et al., 2011). Moreover, the different cucurbit crops are attacking with the twospotted spider mite, Tetranychus urticae Koch. which found as an economic pest infesting cucurbit plants in different planting dates (Foda, 2001; Megali et al., 2003; Al-Ajaln, 2005; Hegab and Hegab, 2009; Awadalla et al., 2011; Gameel, 2013).

Studying the effect of planting dates on the population of insect pests is fundamental basis for planning the integrated pest management programs on a given host plant.

\section{MATERIALS AND METHODS}

\section{Effect of sowing dates on pest populations:}

The present experiments were conducted at the experimental farm belonging to the faculty of agriculture, Mansoura University. The squash plants (var. Eskandrani) was cultivated in the beginning of the third week of March, the first week of June, and the second week of August during the two successive seasons (2014 and 2015). The experimental area was about $400 \mathrm{~m}^{2}$ divided into four replicates (each replicate was about $100 \mathrm{~m}^{2}$ ) for each sowing date for each season. The normal agricultural treatments of land preparation, irrigation, and mechanical weed control were followed, as recommended and chemical control was neglected during the present study. Samples were taken weekly and started one month after plantation date for each season. Samples consisted of 10 leaves from each replicate and were taken weekly until the end of each growing season. The collected leaves (40 leaves for each sample) were transferred to the laboratory into plastic bags for identification and counting. To evaluate the population density of the main pests 200 square inches from each sample (5 square inches/leaf) were taken.

\section{Statistical analysis}

The numbers of pest and predator species on different host plants and during different plantation dates were analyzed using one-way ANOVA and means were separated using Fisher LSD test (Sigma Plot, 2012).

\section{RESULTS AND DISCUSSION}

\section{Effect of planting dates on the main pests attacking} squash plants

Data arranged in Table (1) show the total number and relative abundance of the main pests attacking squash plants at different planting dates during the first season 2014 in Mansoura University. The cotton aphid, $A$. gossypii recorded the highest total number and relative abundance in March plantation followed by the onion thrips, T. tabaci and the cotton mealybug, P. solenopsis and represented by 1863 individuals (53.75\%),761 individuals $(21.9 \%)$, and 320 individuals $(9.2 \%)$, respectively. Moreover, in June plantation, A. gossypii came in the first category and recorded the highest total number and relative abundance followed by the snake cucumber beetle, $H$. argus and represented by 1808 individuals (39.4\%) and 960 individuals (20.9\%), respectively. Meanwhile, in August plantation, the snake cucumber beetle, $H$. argus ranked the first category followed by the cotton aphid, A. gossypii and represented by 1384 individuals (33.8\%) and 925 individuals (22.6\%), respectively. 
Table 1. Total numbers and relative abundances of the main pests attacking squash plants at different planting dates during the first season 2014 at Mansoura region.

\begin{tabular}{lcccccc}
\hline \multirow{2}{*}{ Pest species } & \multicolumn{2}{c}{ March plantation } & \multicolumn{2}{c}{ June Plantation } & \multicolumn{2}{c}{ August Plantation } \\
\cline { 2 - 7 } & No. & \% & No. & \% & No. & \% \\
\hline Aphis gossypii & 1863 & 53.7 & 1808 & 39.4 & 925 & 22.6 \\
Thrips tabaci & 761 & 21.9 & 434 & 9.5 & 137 & 3.3 \\
Bemisia tabaci & 199 & 5.7 & 366 & 8.0 & 834 & 20.4 \\
Empoasca dicipiens & 79 & 2.3 & 341 & 7.4 & 154 & 3.8 \\
Phenococcus solenopsis & 320 & 9.2 & 258 & 5.6 & 403 & 9.9 \\
Thetranychus urticae & 250 & 7.2 & 423 & 9.2 & 253 & 6.2 \\
Henosepilachna argus & 0 & 0.0 & 960 & 20.9 & 1384 & 33.8 \\
\hline Total & 3472 & 100 & 4590 & 100 & 4090 & 100 \\
\hline
\end{tabular}

The obtained results in Table (2) represent the total number and relative abundance of the main pests attacking squash plants at different planting dates during the second season 2015 in Mansoura University. The cotton aphid, $A$. gossypii also came in the first category and recorded the highest total number and relative abundance in March plantation followed by the onion thrips, T. tabaci and represented by 1856 individuals $(55.6 \%)$ and 643 individuals (19.3\%), respectively. Meanwhile, in June plantation, the cotton aphid, A. gossypii ranked the first category and recorded the highest total number and relative abundance followed by the snake cucumber beetle, $H$. argus and represented by 977 individuals (26.6\%) and 893 individuals $(24.3 \%)$, respectively. While, in August plantation, the snake cucumber beetle, $H$. argus came in the first category and recorded the highest total number and relative abundance followed by the cotton whitefly, $B$. tabaci and the cotton mealybug, $P$. solenopsis and represented by 1475 individuals $(46.4 \%), 562$ individuals $(17.7 \%)$, and 431 individuals (13.6\%), respectively.

As a conclusion, data in Tables (1 and 2) indicated that, in March plantation, A. gossypii recorded the highest relative abundance during the first and second season of study ( 53.7 and $55.6 \%$, respectively) followed by $T$. tabaci (21.9 and $19.3 \%$, respectively). On the other hand, the potato leafhopper ranked the last category during the first and second season and represented by 2.3 and $2.1 \%$, respectively. While, the snake cucumber beetle $H$. argus did not occurred during the two seasons in March plantation. In June plantation, A. gossypii recorded the highest relative abundance during the first and second season (39.4 and $26.6 \%$, respectively) followed by $H$. argus (20.9 and $24.3 \%$, respectively). In August plantation, $H$. argus ranked the first category during the first and second season and represented by 33.8 and $44.6 \%$, respectively. Moreover, during the two seasons, June plantation harbored the highest total numbers of the main pests and represented by 4590 and 3673 pests, respectively.

The illustrated results in Table (3) show the average number of the main pests attacking squash plants in the three planting dates during the first season (2014). These results revealed that, $A$. gossypii and $T$. tabaci recorded the highest average number in March plantation (155.25 \pm 13.92 and $63.41 \pm 7.78$ individuals, respectively), while $E$. dicipiens and $T$. urticae recorded the highest average number in June plantation ( $28.42 \pm 4.89$ and $35.25 \pm 5.05$ individuals, respectively). Meanwhile, $B$. tabaci and $P$. solenopsis ranked the first category in August plantation $(69.50 \pm 8.32$ and $33.58 \pm 5.88$ individuals, respectively). Moreover, $H$. argus recorded the highest average numbers for all stages in August plantation.

Table 2. Total numbers and relative abundances of the main pests attacking squash plants at different planting dates during the second season 2015 at Mansoura region.

\begin{tabular}{lcccccc}
\hline \multirow{2}{*}{ Pest species } & \multicolumn{2}{c}{ March plantation } & \multicolumn{2}{c}{ June Plantation } & \multicolumn{2}{c}{ August Plantation } \\
\cline { 2 - 7 } & No. & \% & No. & \% & No. & \% \\
\hline Aphis gossypii & 1856 & 55.6 & 977 & 26.6 & 225 & 7.1 \\
Thrips tabaci & 643 & 19.3 & 176 & 4.8 & 109 & 3.4 \\
Bemisia tabaci & 292 & 8.7 & 451 & 12.3 & 562 & 17.7 \\
Empoasca dicipiens & 69 & 2.1 & 311 & 8.5 & 116 & 3.7 \\
Phenococcus solenopsis & 224 & 6.7 & 407 & 11.1 & 431 & 13.6 \\
Tetranychus urticae & 256 & 7.7 & 458 & 12.5 & 259 & 8.2 \\
Henosepilachna argus & 0 & 0.0 & 893 & 24.3 & 1475 & 46.4 \\
\hline Total & 3340 & 100 & 3673 & 100 & 3177 & 100 \\
\hline
\end{tabular}

The results in Table (4) show the average number of the main pests attacking squash plants in the three planting dates during the second season (2015). The results revealed that, $A$. gossypii and $T$. tabaci recorded the highest average number in March plantation $(154.67 \pm 16.08$ and $53.58 \pm 10.73$ individuals, respectively), while $E$. dicipiens and $T$. urticae recorded the highest average number in June plantation $(25.92 \pm 3.67$ and $38.17 \pm 3.50$ individuals, respectively). Meanwhile, $B$. tabaci and $P$. solenopsis ranked the first category in August plantation (46.83 \pm 6.93 and $35.92 \pm 5.41$ individuals, respectively). Moreover, $H$. argus recorded the highest average numbers for all stages in August plantation. 
Table 3. Effect of planting dates on the average numbers of the main pests attacking squash plants during the first season 2014 in Mansoura region.

\begin{tabular}{lcccc}
\hline \multirow{2}{*}{ Pest species } & \multicolumn{3}{c}{ Average number of pest \pm SE } \\
\cline { 3 - 5 } & & March plantation & June plantation & August plantation \\
\hline Aphis gossypii & $155.25 \pm 13.92 \mathrm{a}$ & $150.67 \pm 15.72 \mathrm{a}$ & $77.08 \pm 15.86 \mathrm{~b}$ \\
Bemisia tabaci & $63.41 \pm 7.78 \mathrm{a}$ & $36.17 \pm 5.79 \mathrm{~b}$ & $11.42 \pm 1.98 \mathrm{c}$ \\
Empoasca decipiens & $16.58 \pm 3.49 \mathrm{~b}$ & $30.50 \pm 3.23 \mathrm{~b}$ & $69.50 \pm 8.32 \mathrm{a}$ \\
Phenococcus solenopsis & & $6.58 \pm 2.07 \mathrm{~b}$ & $28.42 \pm 4.89 \mathrm{a}$ & $12.83 \pm 1.94 \mathrm{~b}$ \\
Tetranychus urticae & & $26.67 \pm 6.09 \mathrm{a}$ & $21.50 \pm 6.66 \mathrm{a}$ & $33.58 \pm 5.88 \mathrm{a}$ \\
& Eggs & $20.83 \pm 4.57 \mathrm{~b}$ & $35.25 \pm 5.05 \mathrm{a}$ & $21.08 \pm 3.30 \mathrm{~b}$ \\
Henosepilachna argus & Larvae & $----------------------~$ & $29.92 \pm 5.21 \mathrm{a}$ & $41.92 \pm 7.74 \mathrm{a}$ \\
& Pupae & --------------15.75 & $25.75 \pm 6.83 \mathrm{a}$ & $33.75 \pm 5.77 \mathrm{a}$ \\
& Adults & $-----------------~$ & $12.00 \pm 3.11 \mathrm{a}$ & $21.83 \pm 5.43 \mathrm{a}$ \\
\hline
\end{tabular}

Values bearing the same small letters in a raw for pests except $\boldsymbol{H}$. argus are not significantly different (ANOVA, Fisher LSD Test), while those of $E$. chrysomelina are separated with $t$-test.

As a conclusion, the obtained results in Tables (3 and 4) revealed that, in March plantation, A. gossypii ranked the first category and recorded the highest average number during the two successive seasons followed by $T$. tabaci with significantly differences. While in June plantation, E. dicipens and T. urticae recorded the highest average number during the two seasons with significant differences. Meanwhile, $P$. solenopsis and $B$. tabaci recorded the highest average number in August plantation during the two seasons with non-significant differences for $P$. solenospis and significant differences for $B$. tabaci. The snake cucumber beetle, $H$. argus recorded the highest average number for all stages in August plantation during the two seasons with non-significant differences during the first season and with significant differences during the second one.

Table 4. Influence of planting dates on the average numbers of the main pests attacking squash plants during the first season 2015 in Mansoura region.

\begin{tabular}{|c|c|c|c|c|}
\hline \multirow{2}{*}{ Pest species } & & \multicolumn{3}{|c|}{ Average number of pest \pm SE } \\
\hline & & March plantation & June plantation & August plantation \\
\hline \multicolumn{2}{|l|}{$\overline{\text { Aphis gossypii }}$} & $154.67 \pm 16.08 \mathrm{a}$ & $81.42 \pm 8.17 b$ & $18.75 \pm 1.93 \mathrm{c}$ \\
\hline \multicolumn{2}{|l|}{ Thrips tabaci } & $53.58 \pm 10.73 \mathrm{a}$ & $14.67 \pm 2.23 b$ & $9.08 \pm 2.17 \mathrm{c}$ \\
\hline \multicolumn{2}{|l|}{ Bemisia tabaci } & $24.33 \pm 2.81 b$ & $37.58 \pm 3.65 \mathrm{a}$ & $46.83 \pm 6.93 \mathrm{a}$ \\
\hline \multicolumn{2}{|l|}{ Empoasca decipiens } & $5.75 \pm 1.39 b$ & $25.92 \pm 3.67 \mathrm{a}$ & $9.67 \pm 2.26 b$ \\
\hline \multicolumn{2}{|l|}{ Phenococcus solenopsis } & $18.67 \pm 5.76 \mathrm{a}$ & $33.92 \pm 4.51 \mathrm{a}$ & $35.92 \pm 5.41 \mathrm{a}$ \\
\hline \multicolumn{2}{|l|}{ Tetranychus urticae } & $21.33 \pm 3.28 \mathrm{~b}$ & $38.17 \pm 3.50 \mathrm{a}$ & $21.58 \pm 3.04 \mathrm{~b}$ \\
\hline \multirow{4}{*}{ Henosepilachna argus } & Eggs & ---------------------' & $36.75 \pm 5.06 \mathrm{a}$ & $40.17 \pm 8.06 \mathrm{a}$ \\
\hline & Larvae & --------------------- & $17.58 \pm 5.46 b$ & $37.17 \pm 9.46 \mathrm{a}$ \\
\hline & Pupae & --------------------- & $11.25 \pm 5.96 b$ & $24.00 \pm 5.30 \mathrm{a}$ \\
\hline & Adults & ---------------------- & $8.83 \pm 3.22 b$ & $21.58 \pm 3.40 \mathrm{a}$ \\
\hline
\end{tabular}

Values bearing the same small letters in a raw for pests except $E$. chrysomelina are not significantly different (ANOVA, Fisher LSD Test), while those of $E$. chrysomelina are separated with $t$-test.

These results are in consistent with those of Pan et al. (2015) in China who evaluated the ecological information for $B$. tabaci and concluded that the population increased in autumn compared to spring season. Sayed and Gameel (2008) in Egypt found that the higher numbers of the melon ladybird E. chrysomelina on cucurbit plants which cultivated in the nili plantation, while the cucurbit plants of the summer plantation suffered the lowest numbers of the insect pest. El-Sayed et al. (1991) suggested that in all plantations, cucumber appeared to be the most infested crop with immature stages of B. tabaci. Awadalla et al. (2011) found that late summer plantation suffered the highest average number of eggs, larvae, and adults of the melon ladybird E. chrysomelina on all tested cucurbit host plants.

\section{REFERENCES}

Abd El-hady, A. A; F. A. shaheen; S.E.Negm; I. H. M. Heikal and D.F.A. El.Asharm (2014). Efficacy of natural compound on the whitefly bemisia tabaci biotype "b" (hemiptera: aleyrodidae) and its natural enemies of cucumber crop. J. Plant Prot. and Path., Mansoura Univ., 5 (12): 1161 - 1176.

Abou El-Saad, A.K. (2015).Incidence of some piercing sucking pests and their natural enemies on watermelon in Assiut governorate. J. Plant Prot. and Path., Mansoura Univ., 6 (2): 389 - 398.

Al-Ajaln, A. M.(2005).Whiteflies Bemisia spp. and thrips Thrips spp. monitored in greenhouses at three districts. Scientific Journal of King Faisal University (Basic and Applied Sciences); 6(2):99107. 
Awadalla, S. S.; Horia A. Abd-Wahab.; N. F. Abd El-Baky and Shymaa S. Abdel-Salam ( 2011 ). Host plant preference of the melon ladybird bettle Epilachna chrysomelina (F.) ( Coleoptera : Coccinellidae) on different cucurbit vegetables in Mansoura region. J. Plant Prot. and Path., Mansoura Univ., 2 (1): 41 47.

El-Fakharany, S.K. (2005). Integrated control of some vegetable crop pests in Kafr El-Sheikh province. Ph.D. Thesis, Fac. Agric., Tanta University, pp. 170.

Foda, M. E.(2001).Population dynamics, host preference and seasonal distribution patterns of whitefly, Bemisia tabaci (Genn.) in middle Egypt. 2000 Proceedings Beltwide Cotton Conferences, San Antonio, USA, 4-8 January, $2: 1380-1382$.

Gameel, S. M. M. (2013). Species composition of piercingsucking arthropod pests and associated natural enemies inhabiting cucurbit fields at the new valley in Egypt. Acad. J. Biolog. Sci, 6(2), 73-79.

Gameel, S. M. M. and Abdel-Gaid (2007). Relative susceptibility of three cucurbit vegetables to the infestation Epilachna chrysomelina F. (Coleoptera- Coccinellidae) at the New Valley Egypt. The 1st International Conference on Desert Cultivation.27-29March, Minia Univ.85-90.

Hegab, Ola, I. M. and Hegab, A. M. S. (2009). Effect of plant varieties and potassium fertilization on the population densities of certain homopterous insects infesting cucumber and squash plant varieties. Egypt . Agric. Sci. Mansoura Univ., 34(3): 21332153.
Megali, M. K.; M.A. Darwish and A.M. Gabr (2003). Population fluctuations of the two spotted spider mite, Tetranychus arabicus Attiah infesting different cucurbit vegetables at different governorates. Egyptian Journal of Agricultural Research, 76(3):983-991.

Pourian, H. R., Mirab-balou, M., Alizadeh, M. and Orosz, S. (2009). Study on biology of onion thrips, Thrips tabaci Lindeman (Thysanoptera: Thripidae) on cucumber (var. Sultan) in laboratory conditions. Journal of Plant Protection Research, 49(4), 390394.

Refaei, E.A.; E.A. El-Sarand and A.A. Khalifa (2016). Population fluctuation of certain sucking insects and their natural enemies associated with seed watermelon, citrullus lanatus at rasheed region, Beheira governorate, Egypt. Egy. J. Plant Pro. Res. 4 (4): 61-69

Younes, M.W.F.; I.I.A. El-Sebaey; A.R.I. Hanagy and Y.N.M. Abd-Allah (2010). Survey of pests and their natural enemies on six cantaloupe Cucumis melo L. varieties in Qaha Region, Qualyobia governorate Egypt, 88: 739-754.

Zanic, K.; D. Ban; T.G.Culjak; S.G.Ban; G.Dumicic;J. Haramija and D. Znidarcic (2013). Aphid populations (Hemiptera: Aphidoidea) depend of mulching in watermelon production in the Mediterranean region of Croatia. Spanish Journal of Agricultural Research; 11(4):1120-1128.



أجريت التجارب الحقلية بالمزر عة البحثية لكلية الزر اعة جامعة المنصورة ، حيث تم زر اعة نباتات الكوسة صنف اسكندر اني فى بداية

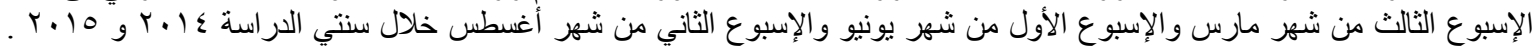

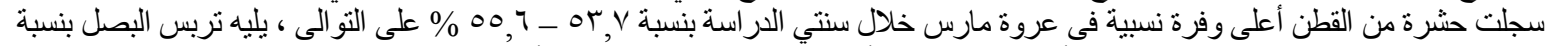

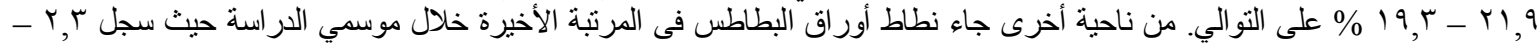

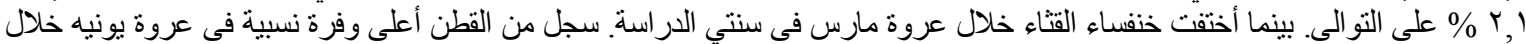

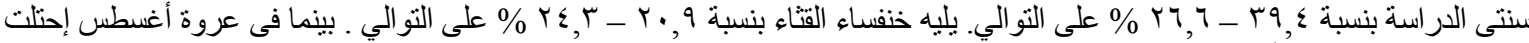

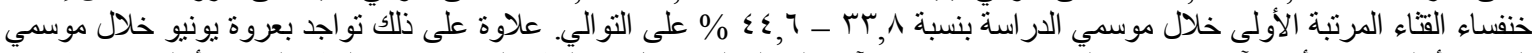



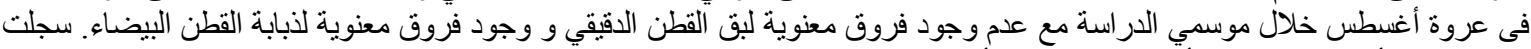

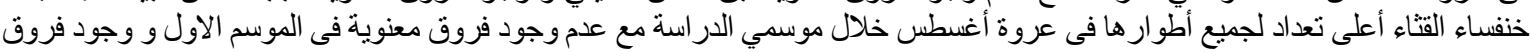
معنوية فى الموسم الثاني. 